Diabetologia 8, 117-124 (1972)

(C) by Springer-Verlag 1972

\title{
Inhibition of Gluconeogenesis from Lactate by Phenylethylbiguanide in the Perfused Guinea Pig Liver
}

\author{
R. Haeckel and H. HaEckel \\ Institut für Klinische Chemie, Medizinische Hochschule Hannover, Hannover, Germany
}

Received: July 26, 1971, accepted: December 6, 1971

Summary. 1. Two hours after the intraperitoneal injection of $12 \mathrm{mg} / \mathrm{kg} 1-\beta$-phenylethylbiguanide (DBI) to guinea pigs fasted $48 \mathrm{~h}$, the 3 -hydroxybutyrate/acetoacetate ratio and the concentration of both lactate and pyruvate were increased in the blood of the vena cava. The glucose level and the lactate/pyruvate ratio were not altered. In perfused livers taken from these animals immediately after the blood samples were withdrawn, the rate of glucose formation from lactate was not inhibited. However, the addition of $2 \times 10^{-5} \mathrm{M}$ DBI to the perfusate caused a $60 \%$ suppression of gluconeogenesis under these conditions. - 2. The accumulation of hepatic acetylS-Co A with a concomitant decrease of the citrate- and of the 2-oxoglutarate concentration in the presence of DBI indicated an impaired synthesis of citrate. A slight reduction of hepatic oxygen consumption was also consistent with an inhibition of the citric acid cycle. It is concluded that biguanides primarily suppressed hepatic cell respiration, which led to an accumulation of reducing equivalents inside the mitochondria. This may have caused a lack of oxalacetate for mitochondrial citrate synthesis. - 3. The pattern of hepatic metabolite concentrations did not clearly show the rate limiting step of glucose formation from lactate in the presence of biguanides, however, some evidence was found that the conversion of pyruvate to phosphoenolpyruvate was affected. - 4. No exact correlation was found between the effect of DBI on gluconeogenesis and on the hepatic ATP/ADP ratio.

Inhibition de la gluconéogénèse à partir du lactate par le phényléthylbiguanide dans le foie perfusé du cobaye

Résumé. Chez des cobayes à jeûn depuis $48 \mathrm{~h}$, l'injection intrapéritonéale de $12 \mathrm{mg} / \mathrm{kg}$ de $1-\beta$-phényléthylbiguanide (DBI) provoque une augmentation du quotient 3-hydroxybutyrate/acéto-acétate et de la concentration de lactate et de pyruvate dans le sang de la veine cave. Le taux de glucose et le quotient lactate/pyruvate n'ont pas changé. La production de glucose à partir du lactate n'a pas été inhibée dans le foie perfusé, examiné immédiatement après la prise de sang. Cependant, l'addition de $2 \times 10^{-5}$ de DBI au perfusat provoque sous ces conditions une baisse de $60 \%$ de la gluconéogénèse. - La concentration. hépatique d'acétyl-S-CoA augmente en présence de DBI, celle de citrate et de 2-oxoglutarate diminue indiquant une perturbation de la synthèse de citrate. On suppose que le DBI inhibe d'abord la respiration cellulaire, puisque la consommation d'oxygène du foie perfusé diminue. II en résulte un accroissement des équivalents réducteurs à l'intérieur des mitochondries, ce qui pourrait amener à un manque d'oxalacétate pour la synthèse de citrate. L'ensemble des différentes concentrations de métabolites hépatiques laisse supposer que la production de phosphoénolpyruvate à partir du pyruvate est inhibée pendant la formation de glucose à partir de lactate en présence de biguanides. - Aucune corrélation exacte $n^{5} a$ été constatée entre l'effet du DBI sur la glu conéogénèse et le quotient ATP/ADP hépatique.

Hemmung der Gluconeogenese aus Lactat durch Phenylaethylbiguanidin der perfundierten Meerschweinchen-Leber.

Zusammenfassung. 1. Die intraperitoneale Injektion von $12 \mathrm{mg} / \mathrm{kg}$ 1- $\beta$-Phenyläthylbiguanid (DBI) bewirkte bei $48 \mathrm{Std}$ gefasteten Meerschweinchen einen Anstieg des 3-Hydroxybutyrat/Acetoacetat Quotienton sowie der Lactat und Pyruvat Konzentrationen im Vena-cava Blut. Der Glucosespiegel und der Lactat/Pyruvat Quotient wurden nicht beeinflußt. In perfundierten Lebern, die unmittelbar nach der Blutentnahme aus diesen Tieren entfernt wurden, war die Glucosebildung aus Lactat nicht gehemmt. Jedoch bewirkte unter diesen Bedingungen die Zugabe von $2 \times 10^{-5}$ M DBI zum Perfusat eine Abnahme der Gluconeogenese um $60 \%$. - 2. Die hepatische Konzentration von Acetyl-S-CoA war in Anwesenheit von DBI angestiegen, die von Citrat und 2-Oxoglutarat abgefallen. Da auch der Sauerstoffverbrauch der perfundierten Leber reduziert war, kann vermutet werden, daß DBI zunächst die Zellatmung hemmte. Dadurch kam es zum Anstieg mitochondrialer Reduktionsäquivalente, der zu einem Mangel an Oxalacetat für die Citratsynthese geführt haben könnte. - 3. Das Muster der hepatischen Metabolitkonzentrationen deutete darauf hin, daß bei der Umwandlung von Lactat in Glucose in Anwesenheit von Biguaniden die Phosphoenolpyruvatbildung aus Pyruvat gehemmt war. - 4. Es wurde keine exakte Korrelation zwischen dem DBI Effekt auf die Gluconeogenese und dem hepatischen ATP/ADP Quotient gefunden.

Key words: Gluconeogenesis, phenylethylbiguanide, perfused guinea pig liver, hepatic redox state.

\section{Introduction}

Since Watanabe's suggestion [1] that the hypoglycemia following parathyroidectomy could be caused by an elevated guanidine content of the blood, many guanidine derivatives have been developed and tested for their use as oral antidiabetic drugs. Pomeranze et al. [2] introduced 1- $\beta$-phenyl-ethylbiguanide, called DBI, into the diabetes therapy.

In the meantime it has been found that DBI increases glucose consumption in muscles [3-6], inhibits glucose uptake from the intestine [7-10] and 
suppresses hepatic gluconeogenesis [11-16]. However, its biochemical mode of action has not been elucidated completely.

We started to reinvestigate the mechanism by which biguanides reduce hepatic glucose formation, using perfused livers from guinea pigs, which are more sensitive to these compounds than are rats [15].

As a result of Hollunger's discovery that biguanides reduce mitochondrial oxygen uptake, the impairment of gluconeogenesis by these compounds has been attributed to a suppression of cell respiration $[17-21]$, Schäfer [22, 23] suggested that these compounds primarily act as blocking agents at the first and second phosphorylating sites. Alterations of mitochondrial electron transfer could influence the $\frac{[\mathrm{ATP}] \times[\mathrm{AMP}]}{[\mathrm{ADP}]^{2}}$ steady state and the ratio of free $\mathrm{NADH}$ to $\mathrm{NAD}^{+}$, both of which control several enzymatic reactions of the gluconeogenetic pathway.

This concept was questioned as a possible in vivo mechanism for the action of biguanides in human diabetics, because higher concentrations of these agents had to be applied for an inhibition of oxygen uptake than are necessary for a blood sugar lowering effect and because the lactate, pyruvate ratio usually did not increase in the blood of patients receiving these drugs $[24,25]$.

The perfused liver appeared to be a suitable system to find out whether possible correlations exist between an effect of DBI on oxygen uptake, gluconeogenesis, lactate/pyruvate and ATP/ADP ratio. In previous communications $[26,27]$ we have reported that biguanides caused a cross-over phenomenon between glycerate-3-phosphate and glyceraldehyde-3phosphate. However, the inhibition of gluconeogenesis by these compounds could not be sufficiently explained by a regulation at this step. In the presence of pyruvate a cross-over point occured between pyruvate and phosphoenolpyruvate. Therefore, further experiments had to be performed to evaluate the role of these possible control sites for the rate of glucose formation.

\section{Materials}

\section{Experimental procedure}

All enzymes and coenzymes were purchased from Boehringer Mannheim, lactate from $\mathrm{E}$. Braun (Melsungen), D, L-glyceric acid from Fluka $A G$ (Buchs, Switzerland), 2,4-dinitrophenol and Dowex $50 \mathrm{WX} 8$ from Serva (Heidelberg), serum albumin (bovine, purified) from Behringwerke AG (Marburg), Uricult from Orion $A G$ (Helsinki) and all other chemicals p.a. grade from Merck AG (Darmstadt). Phenylethylbiguanide hydrochloride ( $\mathrm{MW}=241.7$ ) was a gift from U.S. Vitamin and Pharmaceutical Corp., New York, and D-glycerate from Dr. Weisser (Medizinische Hochschule Hannover).

Male albino guinea pigs of the Pirbright white strain (weighing $300-350 \mathrm{~g}$ ) were fasted $48 \mathrm{~h}$ prior to the perfusion experiments, because we had found the action of biguanides to be more marked under this condition [27].

\section{Perfusion Procedure}

Our perfusion procedure was that of Miller et al. [28] as modified by Schimassek [29]. The animals were anesthesized with ether. One control experiment was usually performed in a twin box together with a second perfusion in which the liver was treated with biguanides.

The perfusate contained $3 \mathrm{~g} / 100 \mathrm{ml}$ albumin, $1 \mathrm{mg}$ sodium ampicillin and bovine erythrocytes washed three times and taken up in Krebs-Ringer bicarbonate solution [30]. The hemoglobin concentration was kept at $5 \mathrm{~g} / 100 \mathrm{ml}$. The experiments were started with $120 \mathrm{ml}$ of the perfusion medium. After the liver was introduced into the perfusion system the first $20 \mathrm{ml}$ of the liver outflow were discarded.

The $\mathrm{pH}$ value was measured with an electrode installed in the perfusate reservoir and kept at 7.4 by the addition of sodium bicarbonate, because we have found the effect of biguanides on gluceneogenesis to be dependent on the extrahepatic hydrogen ion concentration [31].

The aerating gas mixture consisted of $95 \%$ oxygen and $5 \% \mathrm{CO}_{2}$. The blood flow through the liver was measured constantly with a flow meter (Fischer and Porter, D 34 Göttingen) and was approx. $1.5 \mathrm{ml} / \mathrm{min}$ $\times g$ liver with a hydrostatic pressure of $15 \mathrm{~cm}$. The incubation temperature was $37^{\circ} \mathrm{C}$. Bacterial growth was checked occasionally $(9500 \pm 2400(n=7)$ germs/ $\mathrm{ml}$ perfusate). For this purpose $10 \mu \mathrm{l}$ perfusate were withdrawn from the reservoir with a sterilized disposable micropipet and spread out on a glass plate covered with $\mathrm{N}$-agar (Uricult). After $24-48 \mathrm{~h}$ all colonies were counted. Perfusate samples were aspirated from the reservoir for the analysis of metabolites every $15 \mathrm{~min}$. Liver samples were taken at the end of the experiment by the method of Wollenberger et al. [32]. Effectors of gluconeogenesis were added after $45 \mathrm{~min}$ and substrates after $60 \mathrm{~min}$. All perfusion experiments lasted $90 \mathrm{~min}$.

Determination of oxygen consumption and metabolites. For the estimation of the oxygen consumption 4 perfusate samples ( 2 for duplicate measurements of the $\mathrm{pH}$ value and 2 for the determination of the $\mathrm{pO}_{2}$ ) were taken with heparinized glass capillaries (Radiometer Copenhagen) from the in- and outflow of the liver. The venous outflow occured through a polyethylene tube connected with an elastic thin walled rubber tube in which glass capillaries or Hamilton syringes could be introduced conveniently for perfusate sampling without influencing the flow rate. "Arterial" perfusate samples were taken from a small " $T$ " joint inserted in the tube which connected the glass "lung" with the liver. The oxygen concentration was calculated from the hemoglobin concentration and the oxygen saturation. The amount of oxygen saturation was 
estimated from the $\mathrm{pO}_{2}$ and the $\mathrm{pH}$ value using oxygen saturation curves for bovine erythrocytes [33]. Both, the $\mathrm{pO}_{2}$ and the $\mathrm{pH}$ value were measured with an Astrup apparatus (Radiometer, Copenhagen).

Glucose was determined enzymatically with the hexokinase method by an Eppendorf automat 5030 (Eppendorf Gerätebau GmbH, Hamburg) as described recently [34].

All liver metabolites were measured enzymatically in a perchloric acid extract as described earlier [25], acetyl-S-Co A according to Tarnowski and Seemann [35], the concentration of 3-hydroxybutyrate and acetoacetate as reported by Bergmeyer and Bernt [36]. GPT was estimated by the method of Gevers [37]. Drabkin's solution was used for the determination of hemoglobin [38].

In some experiments the animals were pretreated with DBI $(12 \mathrm{mg} / \mathrm{kg}$ or $18 \mathrm{mg} / \mathrm{kg})$ injected intraperitoneally $2 \mathrm{~h}$ prior to the liver perfusion. Immediately after opening the abdomen for the preparation of the liver, blood samples $(0.1-0.2 \mathrm{ml})$ were withdrawn from the vena cava subhepatica and transferred into $1 \mathrm{ml}$ preweighed perchloric acid $(0.33 \mathrm{M})$. The supernatant was neutralized with $3 \mathrm{M} \mathrm{K}_{2} \mathrm{CO}_{3}$ and used for the determination of metabolites. Values of blood concentrations were calculated according to Bergmeyer et al. [39].

Glycerate was precipitated with hot ethanol from D, L-glyceric acid neutralized with saturated barium hydroxide and then taken up in dist. water [40]. A saturated $\mathrm{Na}_{2} \mathrm{SO}_{4}$ solution was added to get rid of most of the barium ions. After centrifugation the supernatant was passed through a Dowex 50 WX 8 (100200 mesh, $\mathrm{Na}^{+}$form) column. The eluate which contained most of the glycerate was free of barium- and sulfate ions. The final concentration of D-glycerate was measured with glyoxylate reductase. This enzyme has been shown to be identical with D-glyceratedehydrogenase [41]. The assay contained $0.9 \mathrm{ml}$ buffer (0.4 M glycine, $0.16 \mathrm{M}$ hydrazine sulfate and $2.1+$ $10^{-3} \mathrm{M}$ EDTA, $\mathrm{pH}$ 9.5), $0.1 \mathrm{ml} \mathrm{NAD}+\left(6 \times 10^{-2} \mathrm{M}\right)$, $0.1 \mathrm{ml}$ sample and $0.02 \mathrm{ml}$ enzyme suspension $(1 \mathrm{mg} /$ $\mathrm{ml})$. Under these conditions the reaction came to an end after approx. $1 \mathrm{~h}$ if the sample contained about $20 \mathrm{nmol}$ of D-glycerate.

\section{Determination of enzyme activities}

In guinea pig liver homogenate, the activity of D-glycerate-kinase was measured as described by Heinz and Lamprecht [42] and of phosphoenolpyruvatecarboxykinase with the method of Nordlie and Lardy [43]. The assay for determining the activity of glycerate-3-phosphate kinase, a modified procedure of Bücher [44], contained $0.5 \mathrm{mM}$ glycerate-3-phosphate, 0.5 to $2.0 \mathrm{mM}$ ATP, $0.14 \mathrm{mM} \mathrm{NADH}, 0.5$ to $6.0 \mathrm{mM}$ $\mathrm{MgSO}_{4}$ and $40 \mathrm{mM}$ triethanolamine $(\mathrm{pH}=7.4)$.

Statistical evaluations were performed by means of the $t$-Test. Differences were considered significant if $P$ was smaller than 0.05 .

\section{Results}

Cross-over phenomenon between glycerate-3-phosphate and glyceraldehyde-3-phosphate.

In perfusion experiments previously reported [27] we observed a cross-over phenomenon in the pattern of hepatic metabilite concentrations between glycerate3-phosphate and glyceraldehyde-3-phosphate in the presence of $8 \times 10^{-5}$ M DBI. Since this effect of biguanides was not found when pyruvate was added to the perfusate, its role for the inhibitory mechanism of these compounds on glucose formation was not clear. Therefore, we looked for a substrate which enters the

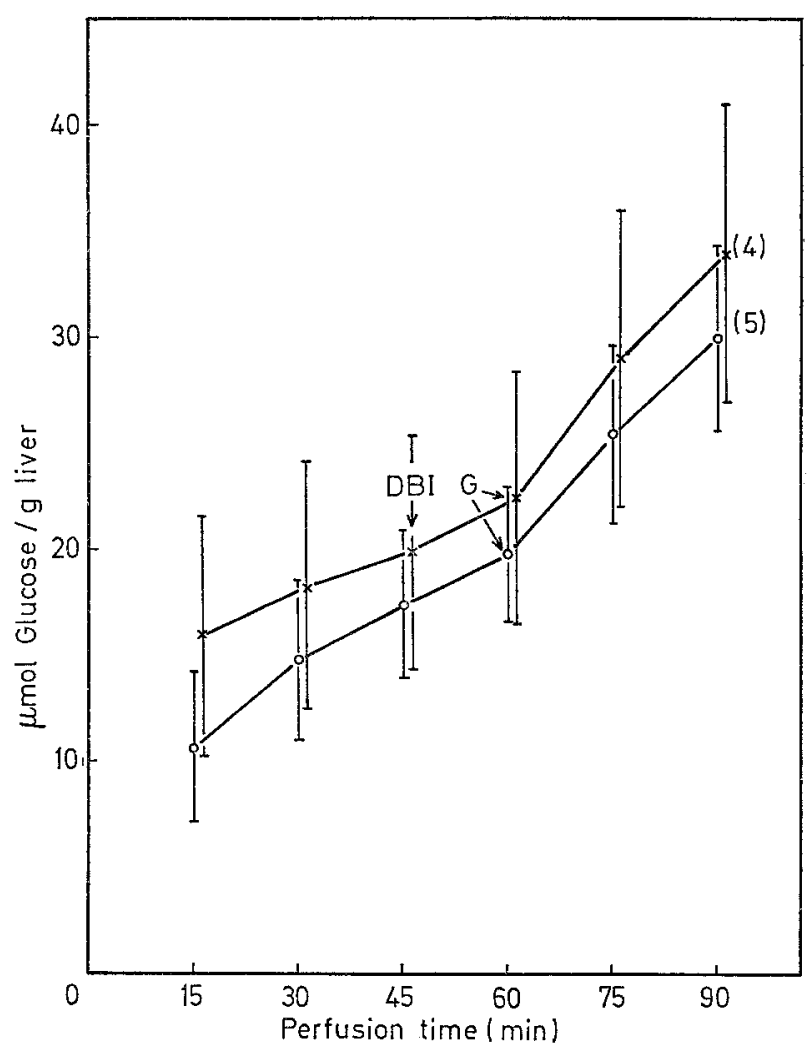

Fig. 1. The influence of $6 \times 10^{-5} \mathrm{M}$ DBI $(x)$ on hepatic glucose formation in the presence of D-glycerate. The rate of gluconeogenesis in control experiments is represented by circles. The addition of glycerate $\left(5 \times 10^{-3} \mathrm{M}\right)$ occured as indicated by arrow (G.) Vertical bars indicate standard deviations

gluconeogenic pathway shortly before the conversion of glycerate-3-phosphate to glyceraldehyde-3-phosphate. D-glycerate, which is phosphorylated to glycerate-2-phosphate $[45,46]$ was choosen for this purpose.

This metabolite, however, was not very effective as precursor for gluconeogenesis (Fig. 1) in the perfused guinea pig liver. This could be explained by the low hepatic activity of D-glycerate kinase which was hardly detectable in the guinea pig $(0.05 \pm 0.02 \mathrm{U} / \mathrm{g}$ liver wet weight, $n=4)$ in comparison with the rat [42]. 
The glucose formed by the perfused guinea pig liver in the presence of glycerate was presumably derived mainly from endogenous precursors. Although $6 \times 10^{-5} \mathrm{M}$ DBI did not affect the rate of gluconeogenesis under these conditions, a marked increase of the glycerate-3-phosphate concentrations occured. It could not be established whether this biguanide effect was caused by an alteration of the ATP/ADP ratio,

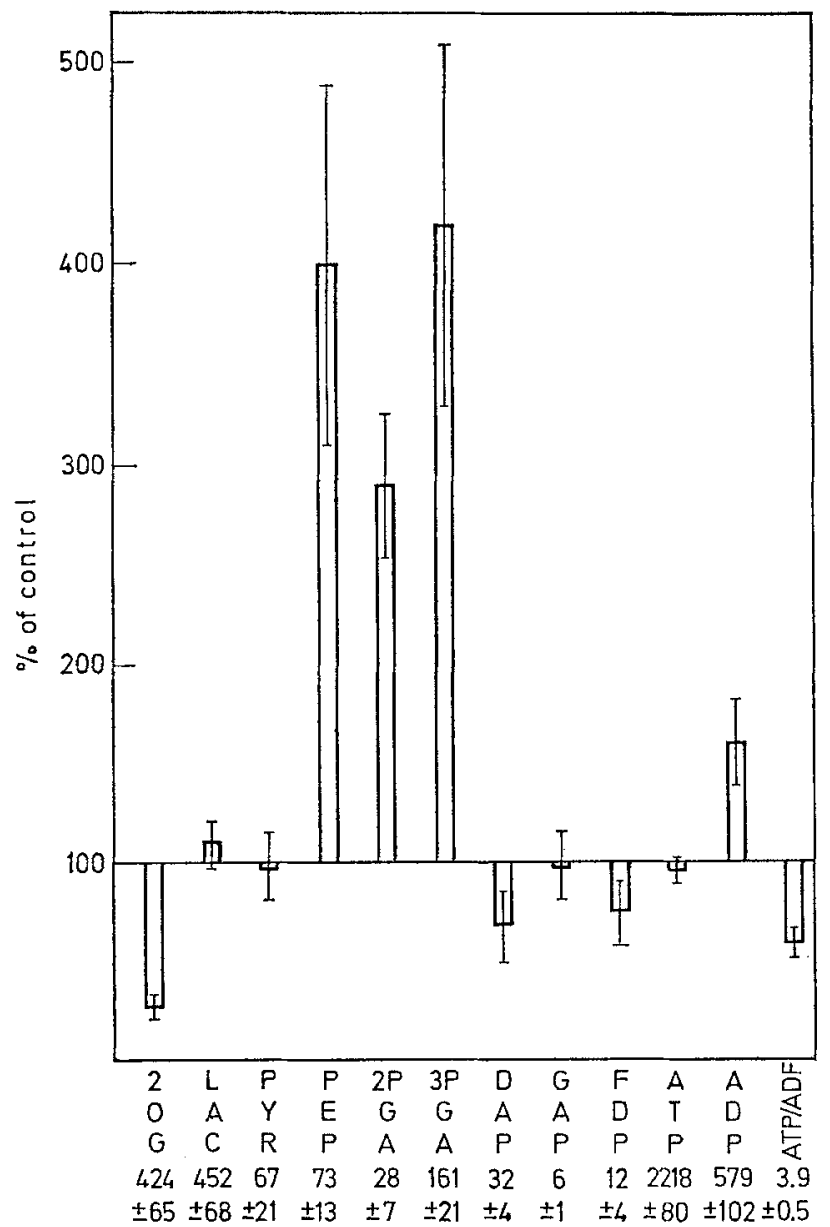

Fig. 2. The influence of DBI $\left(6 \times 10^{-5} \mathrm{M}\right)$ on some glycolytic metabolites in the presence of D-glycerate $\left(5 \times 10^{-3} \mathrm{M}\right)$. Vertical bars indicate standard deviations; absolute values are given in $n m o l / g$ liver wet weight $(n=4)$. LAC means lactate, PYR pyruvate, 2-OG 2-oxoglutarate, PEP phosphoenolpyruvate, 3-PGA glycerate-3-phosphate, GAP glycerinaldehyde-3-phosphate, DAP dihydroxyacetone-3-phosphate, FDP fructose-1,6diphosphate, F-6-P fructose-6-phosphate and G-6-P glucose-6-phosphate

which was reduced significantly $(P<0.01)$. It was not the result of oxidizing conditions in the cytosol for the lactate/pyruvate ratio was not diminished under the same conditions (Fig. 2). DBI concentrations up to $8 \mathrm{mM}$ did not affect the conversion of glycerate-3phosphate to glyceraldehyde-3-phosphate if added to a NADH-coupled assay system using the $100000 \mathrm{~g}$ supernatant fraction of guinea pig liver homogenate [47].

From these results we concluded that the cross-over phenomenon between glycerate-3-phosphate and glyceraldehyde-3-phosphate did not indicate a major control point of gluconeogenesis in the presence of biguanides.

\section{Influence of $D B I$ on some metabolites of the citric acid cycle}

When livers were taken from animals pretreated with DBI (12 mg/kg) two hours before the perfusion experiment was started, $2 \times 10^{-5}$ M DBI inhibited gluconeogenesis from lactate about $60 \%$ (Fig. 3).

Under these conditions the oxygen uptake of these livers was slightly reduced, while a marked increase of the 3-hydroxybutyrate/acetoacetate ratio had occured (Table 1). The elevated sum of the malate and the oxalacetate concentration (Fig. 4) could indicate a regulatory site between both metabolites and PEP in the presence of DBI $\left(2 \times 10^{-5} \mathrm{M}\right)$, although the concentration of PEP was not decreased significantly. A distinct reduction of the PEP concentration might have been prevented by a second effect of DBI on the ratio of PEP plus glycerate-3-phosphate to triosephosphates, which was observed several times under different conditions [27].

The sum of the malate and oxalacetate concentration was considered because both are in equilibrium with each other depending on the intracellular redox state. The increase of malate plus oxalacetate caused by the application of DBI was mainly due to an elevation of the malate and not of the oxalacetate concentration (Table 1).

Higher concentrations of DBI $\left(4 \times 10^{-5} \mathrm{M}\right)$ applied to perfused livers from animals pretreated with $18 \mathrm{mg} /$ $\mathrm{kg}$ of this compound, led to a marked rise of the 3-hydroxybutyrate/acetoacetate ratio and to an almost complete inhibition of glucose formation from lactate (Fig. 3B VI), while the concentration of malate was not further increased. (Table 1).

Since the hepatic concentrations of pyruvate and lactate (Table 2) were elevated it may be assumed that the pyruvate utilisation was affected by DBI.

DBI did not suppress PEP formation by inhibiting PEP-carboxykinase, because even high concentrations of this compound (up to $8 \times 10^{-4} \mathrm{M}$ ) did not affect the conversion of oxalacetate to PEP in liver homogenate fractions. Saturating and limiting concentrations of oxalacetate were used in the assay of the mitochondrial and cytoplasmic enzymes.

Under all conditions reported we have found a marked fall of the hepatic concentration of 2-oxoglutarate under the influence of DBI. Mitzkat [48] observed a similar decrease of this metabolite even in perfused rat livers which were not as sensitive as guinea pig livers with regard to the inhibition of gluconeogenesis by biguanides. The decreased oxygen uptake (Table 1) and the reduced concentration of 2-oxoglutarate and 


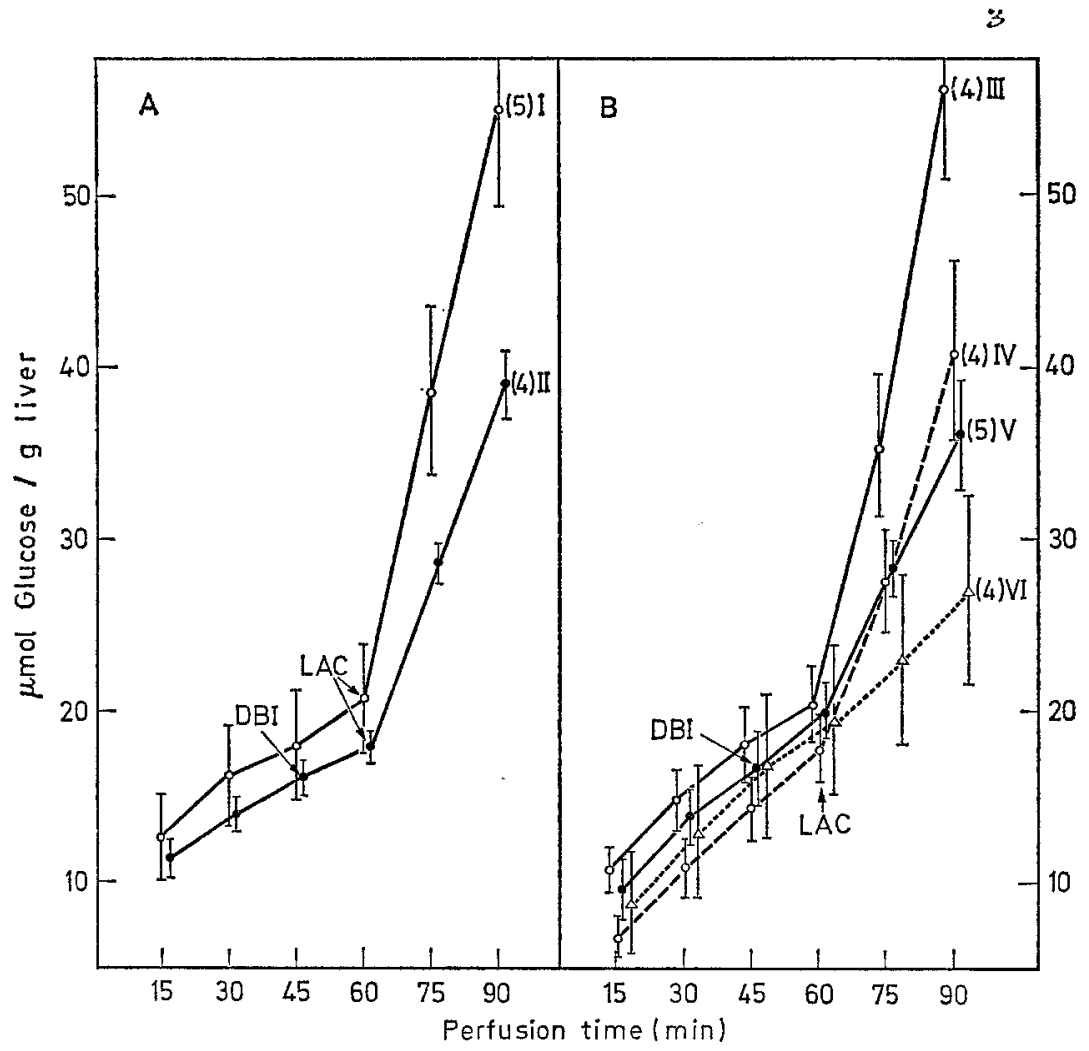

Fig. 3. The rate of glucose formation from lactate $(12 \mathrm{mM})$ as substrate. A. All livers were taken from animals which had not received biguanides prior to the perfusion experiment. B. All livers were taken from guinea pigs after the intraperitoneal injection of DBI $\mathbf{2} \mathrm{h}$ before the perfusion was started. Phenylethylbiguanide was administered in group II $\left(4 \times 10^{-5} \mathrm{M} \mathrm{DBI}\right), \mathrm{V}\left(2 \times 10^{-5} \mathrm{M} \mathrm{DBI}\right)$ and VI $\left(4 \times 10^{-5} \mathrm{M}\right.$ DBI $)$ as indicated by arrows. In all other experiments no inhibitors of gluconeogenesis were added to the perfusate. The animals were pretreated with $12 \mathrm{mg} / \mathrm{kg}$ DBI in group III and $V$, with $18 \mathrm{mg} / \mathrm{kg}$ DBI in group IV and VI. For further explanation see legend to Fig. 1

Table 1. The influence of DBI on hepatic redox couples, the ATP/ADP ratio and the oxygen consumption of perfused livers from guinea pigs pretreated with biguanides $2 h$ before the experiments were starteda

\begin{tabular}{|c|c|c|c|c|}
\hline $\begin{array}{l}\text { DBI, (perfusate) } \\
\text { DBI, mg/kg (i.p. injected) }\end{array}$ & -12 & $\begin{array}{l}2 \times 10^{-5} \mathrm{M} \\
12\end{array}$ & -18 & $\begin{array}{l}4 \times 10^{-5} \mathrm{M} \\
18\end{array}$ \\
\hline Oxygen consumption & $2.7 \pm 0.3^{\mathrm{b}}$ & $2.1 \pm 0.3^{\mathrm{d}}$ & $2.0 \pm 0.2^{\mathrm{d}}$ & $1.7 \pm 0.2^{\mathrm{d}}$ \\
\hline $\begin{array}{l}\text { ATP } \\
\text { ADP } \\
\text { ATP/ADP } \\
\text { GPT }\end{array}$ & $\begin{array}{cl}1820 & \pm 134^{c} \\
806 & \pm 67 \\
2.2 & \pm 0.3 \\
428 & \pm 110\end{array}$ & $\begin{array}{cl}1536 & \pm 131 \\
826 & \pm 69 \\
1.9 & \pm 0.2 \\
439 & \pm 120\end{array}$ & $\begin{aligned} 1887 & \pm 199 \\
907 & \pm 195 \\
2.0 & \pm 0.4\end{aligned}$ & $\begin{aligned} 1533 & \pm 327 \\
936 & \pm 154 \\
1.6 & \pm 0.3^{đ}\end{aligned}$ \\
\hline $\begin{array}{l}\text { Lactate/Pyruvate } \\
\text { 3-Hydroxybut./Acetoacetate }\end{array}$ & $\begin{array}{cc}27.8 \pm & 3.8 \\
0.51 \pm & 0.11\end{array}$ & $\begin{array}{ll}35.1 \pm & 5.9^{\mathrm{d}} \\
0.85 \pm & 0.21^{\mathrm{d}}\end{array}$ & $\begin{array}{ll}26.5 \pm & 4.5 \\
1.25 \pm & 0.4^{\mathrm{d}}\end{array}$ & $\begin{array}{l}37.5 \pm \\
2.51 \pm \quad 0.6^{\mathrm{d}}\end{array}$ \\
\hline $\begin{array}{l}\text { 3-Hydroxybutyrate } \\
\text { Acetoacetate } \\
\text { Malate } \\
\text { Oxalacetate }\end{array}$ & $\begin{aligned} 585 & \pm 148 \\
1150 & \pm 380 \\
384 & \pm 111 \\
21 & \pm 2\end{aligned}$ & $\begin{array}{cc}653 & \pm 124 \\
766 & \pm 174 \\
761 & \pm 43^{\mathrm{d}} \\
20 & \pm 3\end{array}$ & $\begin{array}{l} \pm 161 \\
\pm 177^{\mathrm{d}} \\
\pm 180\end{array}$ & $\begin{array}{ll}682 & \pm 182 \\
273 & \pm 104^{\mathrm{d}} \\
695 & \pm 63^{\mathrm{d}}\end{array}$ \\
\hline
\end{tabular}

a Experimental conditions: see under methods. Substrate: lactate.

b $\mu \mathrm{mol} / \mathrm{g}$ liver (wet weight). Min.

c $\mathrm{nmol} / \mathrm{g}$ liver (wet weight) with standard deviation $(n=4)$.

d These values differs significantly from the control values (first column).

citrate in connexion with the increase of the acetyl-SCo A level in the presence of DBI (Fig. 4) indicated a suppression of the citric acid cycle. Similiar results were obtained with minced liver preparations [49].
$D B I$ effect on venous redox systems

In guinea pigs fasted $48 \mathrm{~h}$, DBI (12 $\mathrm{mg} / \mathrm{kg}$ ) injected intraperitoneally $2 \mathrm{~h}$ before blood samples were taken, did not alter the venous glucose concentration 
and the lactate/pyruvate ratio. However, the 3-hydroxybutyrate/acetoacetate ratio was increased by about $100 \%$ (Table 2). The concentrations of both lactate and pyruvate were slightly elevated, while the concentration of 3-hydroxybutyrate and acetoacetate were not changed.

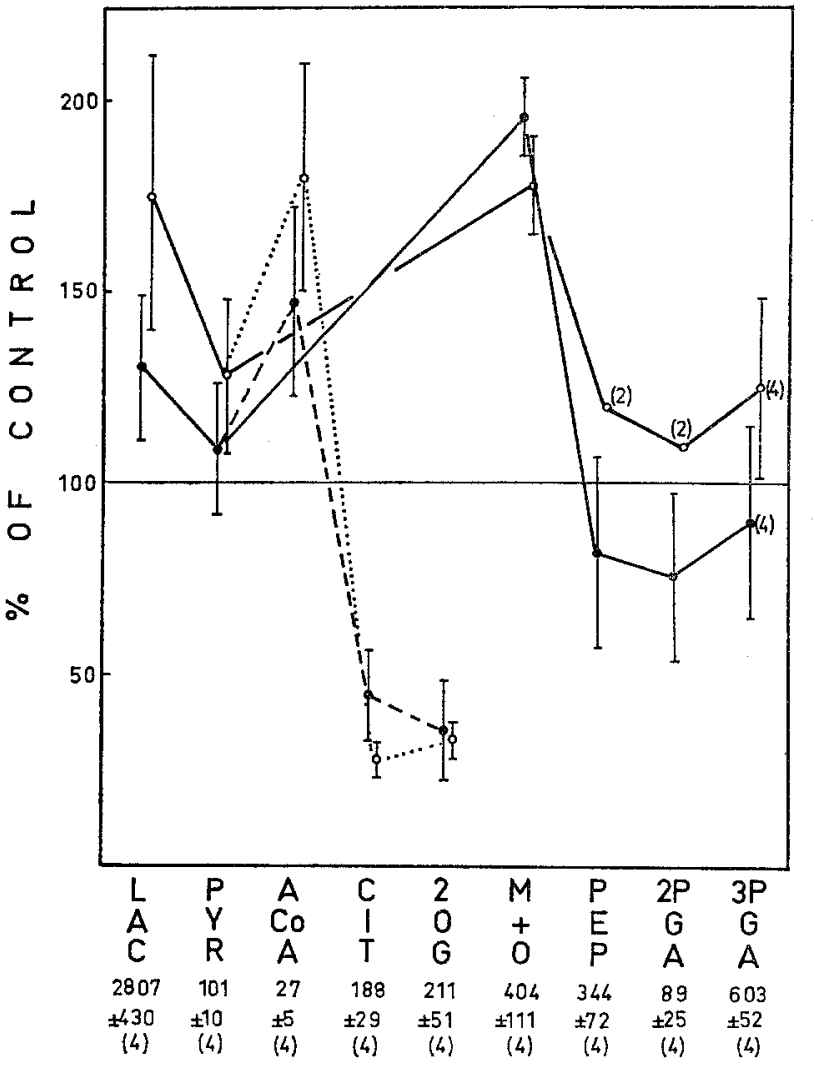

Fig. 4. The pattern of some gluconeogenic metabolites in perfused guinea pig livers in the presence of DBI $\left(2 \times 10^{-5}\right.$ M). Substrate: lactate, $12 \mathrm{mM}$. All livers were taken from animals pretreated either with $12 \mathrm{mg} / \mathrm{kg}$ DBI (-) or with $18 \mathrm{mg} / \mathrm{kg}$ DBI (open circles) $2 \mathrm{~h}$ before the perfusion experiment was started. A Co A means acetyl-S-Co A, CIT citrate, 2 OG 2-oxoglutarate. For further explanation see legend to Fig. 2

\section{Discussion}

It is well established and also confirmed by most of our experiments, that biguanides can decrease the hepatic ATP concentration. Several authors [15, 18-20] attributed this effect to the inhibition of gluconeogenesis by these compounds. However, two results were not consistent with this theory:

1. In perfused livers from animals pretreated with $12 \mathrm{mg} / \mathrm{kg}$ DBI, the ATP/ADP ratio (Table 1) was decreased to 2.2 (controls: $4.5 \pm 0.4, n=5$ ), while gluconeogenesis was not effected (Fig. 3).

2 . Under the same experimental conditions the application of DBI $\left(2 \times 10^{-5} \mathrm{M}\right)$ to the perfusate led to a reduction of gluconeogenesis (Fig. 3 ) without affecting the ATP/ADP ratio significantly (Table 1).
Under various experimental conditions cross-over points were observed in the pattern of hepatic metabolites at two steps of the gluconeogenetic pathway which are controlled by nucleotides.

One cross-over phenomenon occured between glycerate-3-phosphate and glyceraldehyde-3-phosphate

Table: 2. The influence of $D B I$ injected intraperitoneally on the venous concentration of some metabolites in guinea pigs fasted $48 \mathrm{~h}^{\mathrm{a}}$

\begin{tabular}{|c|c|c|}
\hline DBI, $\mathrm{mg} / \mathrm{kg}$ & 一 & 13 \\
\hline Glucose & $\begin{array}{l}6149 \pm 194^{b} \\
(14)\end{array}$ & $\begin{array}{l}6116 \pm 450 \\
(7)\end{array}$ \\
\hline Lactate & $\begin{array}{l}2800 \pm 527 \\
(10)\end{array}$ & $\begin{array}{l}3790 \pm 492 \\
(8)\end{array}$ \\
\hline Pyruvate & $\begin{array}{l}180 \\
(10)\end{array} 45$ & $\begin{array}{c}260 \\
(8)\end{array} \pm 54$ \\
\hline Lactate/Pyruvate & $\begin{array}{l}15.5 \pm \quad 3.0 \\
(10)\end{array}$ & $\begin{array}{l}14.6 \pm \\
(8)\end{array}$ \\
\hline 3-Hydroxybutyrate & $\begin{array}{l}206 \\
(9)\end{array}$ & $\frac{247}{(8)} \pm 70$ \\
\hline Acetoacetate & $\begin{array}{l}148 \\
(9)\end{array} \pm 64$ & $\begin{array}{l}79 \\
(8)\end{array} \quad \pm 21$ \\
\hline $\begin{array}{l}\text { 3-Hydroxybut./ } \\
\text { Acetoacetate }\end{array}$ & $\frac{1.4}{(9)} \pm 0.3$ & $(8)^{3.1 \pm 0.7}$ \\
\hline 2-Oxoglutarate & $\frac{29}{(10)} \pm 6$ & $\begin{array}{c}34 \\
(8)\end{array}$ 土 \\
\hline
\end{tabular}

a Experimental conditions: see under methods

b All metabolites are given in nmol/ml with standard deviation and number of contributing values.

which was probably not essential for the effect of biguanides on gluconeogenesis as pointed out above. However, it appeared important to know about this fact since it may have masked other regulatory sites of these compounds in the pattern of the gluconeogenetic metabolites, which apparently occured before this step.

In livers from animals pretreated with biguanides, DBI caused another cross-over point between oxalacetate plus malate and PEP. The conversion of oxalacetate to PEP is dependent on the presence of GTP, which is formed either by substrate phosphorylation in the citric acid cycle or from ATP by nucleoside-diphosphate kinase [50-52]. The rough estimation of the GTP concentration by the method od Gevers [37] did not reveal a significant effect of DBI $\left(2 \times 10^{-5} \mathrm{M}\right)$ added to the medium on the GTP level of perfused livers from donor animals pretreated with biguanides (Table 1).

However, for a final decision, more accurate determinations of hepatic nucleotides are needed. It may also be possible that a marked reduction of the mitochondrial GTP pool, which could have been caused by DBI, was not detectable by this method.

A major role in the elevation of the hepatic malate concentration may have been played by an increase of the ratio of free $\mathrm{NADH}$ to $\mathrm{NAD}^{+}$. It has also been 
shown in isolated mitochondria [53] that malate production was stimulated and the synthesis of both PEP and citrate decreased from all substrates tested when the ratio of free $\mathrm{NADH}$ to $\mathrm{NAD}^{+}$was elevated. The alteration of the 3-hydroxybutyrate/acetoacetate ratio by DBI (Table 1 and 2) indicated an accumulation of reducing equivalents in the mitochondrial compartment. The concentration of oxalacetate was not altered by DBI in the perfused liver; however, it must be realized that the determination of this metabolite is very unreliable because of its instability, and that $99 \%$ of the total hepatic concentration is located outside the mitochondria [54]. Calculations of the oxalacetatefrom the malate concentration and from the ratio of free $\mathrm{NADH}$ to $\mathrm{NAD}^{+}$cannot be performed as long as it is not established which redox couple of the guinea pig liver can be used for this purpose.

Recently, we have found that the alteration of the glutamate/ 2-oxoglutarate $\times \mathrm{NH}_{4}{ }^{+}$ratio was not followed by the 3-hydroxybutyrate/acetoacetate ratio under the influence of $2 \times 10^{-5} \mathrm{M}$ DBI [27] and that the glutamate dehydrogenase system did not reflect the mitochondrial redox state in the presence of alanine [55]. Similar observations were reported by Willms et al. [56] who came to the conclusion that two separated pools of free NADH are presumably present in mitochondria of the guinea pig liver.

Under our experimental conditions biguanides presumably inhibited cell respiration slightly, but effective enough to cause accumulation of reducing equivalents inside the mitochondria. Oxalacetate was directed towards malate, and was therefore less available for citrate- and PEP synthesis.

According to Garber and Ballard [53, 57] the PEP formation occurs mainly inside of guinea pig liver mitochondria.

The increase of the hepatic lactate plus pyruvate concentrations indicated that biguanides may have affected gluconeogenesis at a step between pyruvate and oxalacetate. We cannot decide from our data, whether pyruvate carboxylation or its mitochondrial uptake could have been influenced by these compounds Since the hepatic concentration of acetyl-S-Co A was increased, we conclude that mitochondrial uptake was not the rate limiting step. Under our eperimental conditions, maintainance of the intracellular acetyl-S-Co A level is dependent on the pyruvate oxidation. This can be shown with indolcarboxylic acids [58], which are known to inhibit pyruvate oxidation $[59,60]$. Thus, we assume that DBI may have affected pyruvate carboxylation by an unknown mechanism. Schäfer [61] did not detect a distinct influence of this compound on the pyruvate carboxylase activity of rat liver.

In guinea pigs pretreated with $12 \mathrm{mg} / \mathrm{kg}$ DBI (Table 2), a dosage which was only $2-3$ times above that usually applied to human diabetics, the lactate/ pyruvate ratio was not altered although the 3-hydroxybutyrate/acetoacetate ratio was increased $200 \%$. From these results we conclude that an effect of bi- guanides on the mitochondrial redox state or on cell respiration cannot be excluded by an unaltered lactate/ pyruvate ratio as has been done by several authors $[24$, 25].

Acknowledgement. Excellent technical assistance from Mrs. U. Strewe is thankfully acknowledged. This work was supported by Deutsche Forschungsgemeinschaft, Bad Godesberg.

\section{Literatur}

1. Watanabe, C.K.: Hypoglycemic property of guanidine. J. biol. Chem. 33, 253-262 (1918).

2. Krall, L.P., Camerini-Davalos, R.: Early clinical evaluation of a new oral non-sulfonylurea hypogly. cemic agent. Proc. Soc. exp. Biol. Mod. 95, 345-347 (1957).

3. Lyngsoe, J., Trap-Jensen, J.: Phenformin induced hypoglycemia in normal subjects. Brit. med. J. 1969 II, $224-226$.

4. Butterfield, W.J.H., Whichelow, M.J.: Effect of phenformin on glucose metabolism in peripheral tissues. Diabetes 2, 281-286 (1962).

5. - - Effect of diet, sulfonylureas, and phenformin on peripheral glucose uptake in diabetes and obesity. Lancet $1968 \mathrm{II}, 785-788$.

6. Williams, R.H., Tybergheim, J.H., Hyde, P.M., Nielsen, R.L.: Studies related to the hypoglycemic action of phenethylbiguanide. Metabolism 6, 311-319 (1957).

7. Searle, G.L., Cavalieri, R.R.: Glucose kinetics before and after phenformin in the human subject. Ann. N.Y. Acad. Sci. 148, 734-742 (1968).

8. Kruger, F.A., Altschuld, R.A., Hollobaugh, S.L., Jewett, B.: Studies on the site and mechanism of action of phenformin. Diabetes 19, 50-52 (1970).

9. Berchtold, P., Bodi, P., Arbenz, U., Keiser, G.: Intestinale Absorptionsstörung infolge Metforminbehandlung. Diabetologiea 5, 405-412 (1969).

10. Czyzyk, A., Lawecki, J., Sadowski, J., Ponikowska, J., Szczepanik, Z.: Effect of biguanides on intestinal absorption of glucose. Diabetes 17, $492-498$ (1968).

11. Meyer, F., Ipaktchi, M., Clauser, H.: Specific inhibition of glucogenesis by biguanides. Nature 213, 203-204 (1967).

12. Nielsen, R.L., Swanson, H.E., Tanner, D.C., Williams, R.H., O'Connell, M.: Effects on blood sugar of a new potent hypoglycemic compound. Arch. intern. Med. 101, 211-215 (1958).

13. Beringer, A., Geyer, G, G., Mösslacher, H., Tragl, K.H., Thaler, H.: Die Wirkung von Buformin auf den Leberstoffwechsel. $2^{\text {nd }}$ Internat. Biguanid. Symp., Düsseldorf, May 5 and 6, 1967, 43-51, Herausgeber: K. Oberdisse, H. Daweke, G. Michael.

14. - Zur Behandlung der Zuckerkrankheit mit Biguaniden, Wien. med. Wschr. 108, 880-882 (1958).

15. Altschuld, R.A., Kruger, F.A.: Inhibition of hepatic gluconeogenesis in guinea pig by phenformin, Ann. N.Y. Acad. Sci. 148, 612-622 (1968).

16. Losert, W.: Untersuchungen zu der durch Buformin im Tierexperiment verursachten Hypoglykämie, Archiv. Pharmak. 264, 275-284 (1969).

17. Hollunger, G.: Guanidines and oxidative phosphorylation, Acta Pharm. Toxicol. 11, Suppl. 1, 1-84 (1955).

18. Kruger, F.A., Skillman, T.G., Hamwi, G.J., Grubbs, R.C., Danforth, N.: The mechanism of action of hypoglycemic guanidino derivatives, Diabetes $\mathbf{9}$, $170-173(1960)$.

19. Wick, A.N., Larson, E.R., Serif, G. S.: A site of action of phenethylbiguanide, a hypoglycemic compound, J. biol. Chem. 233, 296-302 (1958). 
20. Steiner, D.F., Williams, R.H. : Actions of phenethylbiguanide and related compounds, Diabetes $8,154-$ $161(1959)$

21. Pressmann, B.C.: The effects of guanidine and alkyl guanidines on the energy transfer reactions of mitochondria. J. biol. Chem. 238, $401-409$ (1963).

22. Schäfer, G.: Site-specific uncoupling and inhibition of energy transfer by biguanides, Biochem. biophys. Acta 93, 279-283 (1964).

23. - Site specific uncoupling and inhibition of oxidative phosphorylation by biguanides, Biochem. biophys. Acta 172, 334-337 (1969).

24. Tranquada, R.E., Kleeman, C., Brown, J.S.: Some effects of phenethylbiguanide on human hepatic metabolism as measured by hepatic vein catheterization. Diabetes 9, 207-214 (1960).

25. Güttler, E.M., Petersen, F.B., Kjeldsen, K.: The influence of phenformin on blood lactic acid in normal and diabetic subjects during exercise. Diabetes 12, $420-423(1963)$.

26. Haeckel, R., Haeckel, H.: Interference of ethanol oxidation with gluconeogenesis in the perfused guinea pig liver. Biochemistry 7, 3803-3810 (1968).

27 . - - On the inhibition of gluconeogenesis by $1-\beta$ phenyl-ethylbiguanide in the perfused guinea pig liver. In (H.D. Söling, B. Willms, eds.) Regulation of Gluconeogenesis 127-139. Stuttgart: Thieme Verlag 1971.

28. Miller, L.L., Bly, C.G., Watson, M.L., Bale, W.F.: The dominant rôle of the liver in plasma protein synthesis, J. exp. Med. 94, 431-442 (1951).

29. Schimassek, H.: Metabolite des Kohlenhydratstoffwechsels der isoliert perfundierten Rattenleber, Biochem. Z. 336, 460-467 (1963).

30. Umbreit, W.W., Burris, R.H., Stauffer, J.F.: Manometric Techniques 4. Ausgabe. Minneapolis: Burgers Publishing Company1964.

31. Haeckel, R., Haeckel, H., Anderer, M.: The influence of extracellular hydrogen ions on the inhibition of gluconeogenesis by butylbiguanide in the perfused guinea pig liver, Biochem. Pharmacol. 20, 1053-1060 (1971).

32. Wollenberger, A. Krause, E.G., Mahler, B. E.: Orthophosphat- und Phosphatkreatingehalt des Herzmuskels. Naturwissenschaften 45, 294-295 (1958).

33. Bartels, H., Harms, H. : Sauerstoffdissoziationskurven des Blutes von Säugetieren. Pflügers Archiv 268, 334-365 (19.59).

34. Haeckel, R.: The rapid, enzymatic determination of glucose in hemolysates. Z. klin. Chem. klin. Biochem. 8, $480-482(1970)$.

35. Tarnowski, W., Seemann, M.: Konzentrationsänderungen von Effektoren gluconeogenetischer Schlüsselenzyme in der Rattenleber unter gluconeogenetischen Bedingungen. Hoppe-Seyler's Z. physiol. Chem. 348, 829-838 (1967).

36. Bergmeyer, H.U., Bernt, E.: Enzymatische Bestimmung von Keton-Körpern im Blut. Enzym. biol. clin. $5,65-76$ (1965).

37. Gevers, W.: The regulation of phosphoenolpyruvate synthesis in pigeon liver. Biochem. J. 103, 141-152 (1967).

38. Drabkin, D.L., Austin, J.H.: Preparations from washed blood cells; nitric oxide hemoglobin and sulfhemoglobin, J. biol. Chem. 112, 51-88 (1935).

39. Bergmeyer, H. U.: Methoden der enzymatischen Analyse. Weinheim: Verlag Chemie 1970.

40. Wohl, A., Schellenberg, R.: Die Úberführung des aktiven Glycerinaldehyds in die aktive Glycerinsäure. Ber. dtsch. Chem. Ges. 55, 1404-1408 (1922).

41. Laudahn, G.: Vergleichende Untersuchungen zum Umsatz von Pyruvat, Hydroxypyruvat und Glyoxalat durch die NAD-Oxydoreduktasen Lactat-dehydrogenase, Glyoxylat-Reduktase und D-Glycerat-dehydrogenase, Biochem. Z. 337, 449-461 (1963).

42. Heinz, F., Lamprecht, W.: Enzyme des Fructosestoff. wechsels Z. physiol. Chem. 348, 855-63 (1967).

43. Nordlie, R.C., Lardy, H.A.: Mammalian liver phosphoenolpyruvate carboxikinase activities, J. biol. Chem. 238, 2259-2263 (1963).

44. Bücher, Th.: Über ein phosphatübertragendes Gärungsferment. Biochim. biophys. Acta 1, 292-314 (1947).

45. Dickens, F., Williamson, H.D.: Metabolism of d- and 1-(3- $\left.{ }^{14} \mathrm{C}\right)$ glycerate by liver tissue of the rat. Biochem. J. 77, 356-363 (1960).

46. Heinz, F., Bartelson, K., Lamprecht, W.: D-Glyceratdehydrogenase aus Leber. Z. physiol. Chem. 329, $222-240$ (1962).

47. Haeckel, R.: Unpublished results.

48. Mitzkat, H.J., in: $2^{\text {nd }}$ Internat. Biguanid Symp p. 28 (Herausgeber: K. Oberdisse, H. Daweke und G. Michael). Stuttgart: G. Thieme-Verlag 1968.

49. Jangaard, N.O., Pereira, J. N., Pinson, R.: Metabolic effects of the biguanides and possible mechanism of action. Diabetes 16, 96-104 (1967).

50. Heldt, H.W., Klingenberg, M.: Endogenous nucleotides of mitochondria participating in phosphat transfer reactions as studied with ${ }^{32} \mathrm{p}$ labelled orthophosphate and ultramicro scale ion exchange chromatography. Biochem. Z. 343, 433-451 (1965).

51. Ishihara, N., Kikuchi, G.: Studies on the functional relationship between the phosphopyruvate synthesis and the substrate level phosphorylation in guinea pig liver mitochondria. Biochim. biophys. Acta 153, 733 (1968).

52. Somberg, E.W., Mehlman, M.: The regulation of mitochondrial pyruvate metabolism in guinea pig liver synthesizing precursors for gluconeogenesis. Biochem. J. 112, 435-447 (1969).

53. Garber, A.J., Ballard, F.J.: Regulation of PEP metabolism in mitochondria from guinea pig liver. J. biol. Chem. 245, 2229-2240 (1970).

54. Williamson, J.R., Olson, M.S.: Control of citrate and acetoacetate synthesis in rat liver. Biochem. biophys. Res. Commun. 32, 794 799 (1968).

55. Haeckel, R., Haeckel, H.: The influence of alanine on the glutamate/oxoglutarate $\mathrm{x} \mathrm{NH}_{4}^{+}$ratio in the guinea pig liver. FEBS Letters 9, 15-16 (1970).

56. Willms, B., Kleinicke, J., Söling, H.D.: On the redox state of NAD+/NADH Systems in guinea pig liver under different experimental conditions, in: (H.D. Söling, B. Willms, eds.) Regulation of gluconeogenesis 103-113. Stuttgart: Thieme Verlag 1971.

57. Garber, A.J., Hanson, R.W.: The interrelationships of the various pathways forming gluconeogenenic precursors in guinea pig liver mitochondria. J. biol. Chem. 246, 589-598 (1971).

58. Haeckel, $R$., in preparation.

59. Hanson, R.L., Ray, P.D., Walter, P., Lardy, H.A.: Inhibition of gluconeogenesis by quinaldic acid and 5-methoxyindole-2-carboxylic acid. J. biol. Chem. 244, $4351-4359$ (1969).

60. Reed, J., Lardy, H.A.: Studies on 5-methoxyindole2-carboxylic acid and quinaldic acid. J. biol. Chem. 245, 5297-5303 (1970).

61. Schäfer, G.: personal communication.

Priv.-Doz. Dr. R. Haeckel, Medizinische Hochschule Hannover, Institut für klinische Chemie, D-3000 Hannover-Kleefeld Roderbruchstr. 101 Germany 